\title{
Effects of gene disruptions in the nisin gene cluster of Lactococcus lactis on nisin production and producer immunity
}

\author{
Runar Ra, ${ }^{1}$ Marke M. Beerthuyzen, ${ }^{2}$ Willem M. de Vos, ${ }^{2}$ Per E. J. Saris ${ }^{1}$ \\ and Oscar P. Kuipers ${ }^{2} \dagger$ \\ Author for correspondence: Oscar P. Kuipers. Tel: +3150 3632093. Fax: +31503632105. \\ e-mail: o.p.kuipers@biol.rug.nl
}

\footnotetext{
1 Department of Applied Chemistry and Microbiology, PO Box 56 00014 University of Helsinki, Finland

2 Microbial Ingredients Section, NIZO food research, PO Box 20, 6710 BA Ede, The Netherlands
}

\begin{abstract}
The lantibiotic nisin is produced by several strains of Lactococcus lactis subsp. lactis. The chromosomally located gene cluster nisABTCIPRKFEG is required for biosynthesis, development of immunity, and regulation of gene expression. Inframe deletions in the nisB and nisT genes, and disruption of nisC by plasmid integration, eliminated nisin production and resulted in a strongly reduced level of immunity of the strains. The transcription of two nisin operons was inactivated in these mutant strains, but could be restored by addition of small amounts of nisin to growing cultures. The immunity levels of the mutants were also raised by adding nisin to growing cultures, albeit not to wild-type level. A strain with an in-frame deletion in the nisl gene was still able to produce active nisin, but the production and immunity levels were markedly lower. By measuring immunity levels of the knock-out strains and determining mRNA levels, it is concluded that Nisl has an important function for nisin immunity and must cooperate with nisFEG-encoded proteins to provide a high level of immunity. Maximal immunity could not be obtained in the mutant strains, probably because the wild-type transcription levels from nisA and nisf promoters are not reached when essential nis genes are disrupted. Using Southern hybridization with a consensus promoter probe, no other DNA sequences similar to the nisA and nisF promoters could be detected, indicating that these two elements are probably the only ones in the chromosome regulated by nisin and are thus the only ones involved in the regulation of producer immunity.
\end{abstract}

Keywords: Lactococcus lactis, nisin, producer immunity, in-frame deletions

\section{INTRODUCTION}

The antimicrobial peptide nisin belongs to the family of lantibiotics and is produced by several strains of Lactococcus lactis (Hurst, 1981). It is used as a natural preservative in the food industry because it inhibits the growth of food-spoilage bacteria (Delves-Broughton et al., 1996). Nisin is ribosomally synthesized as a precursor peptide that undergoes post-translational modifications, i.e. dehydration of serine and threonine residues and formation of five intramolecular thioether ring structures called ( $\beta$-methyl)lanthionine residues (Gross $\&$ Morell, 1971). The eleven genes required for nisin

\footnotetext{
† Present address: RUG, PO Box 14, 9750 AA Haren, The Netherlands.
}

synthesis are located in a gene cluster on the nisinsucrose transposon Tn5276 (Buchman et al., 1988; Kaletta \& Entian, 1989; Steen et al., 1991; Rauch \& de Vos, 1992; Engelke et al., 1992; van der Meer et al., 1993; Kuipers et al., 1993; Engelke et al., 1994; Immonen et al., 1995; de Vos et al., 1995a, b; Siegers \& Entian, 1995). The organization of these genes is shown in Fig. 1. The nis $A$ gene encodes the 57 aa precursor peptide; $n i s B$ and nis $C$ probably encode membrane-associated proteins that are involved in the postranslational modification of nisin (Engelke et al., 1992; Kuipers et al., 1993; Siegers et al., 1996). nis T encodes a protein that shares significant homology with ATP-dependent translocator proteins, and recently it has been shown that Nis $\mathrm{T}$ is involved in the translocation of the fully modified precursor nisin across the cytoplasmic membrane (Qiao 


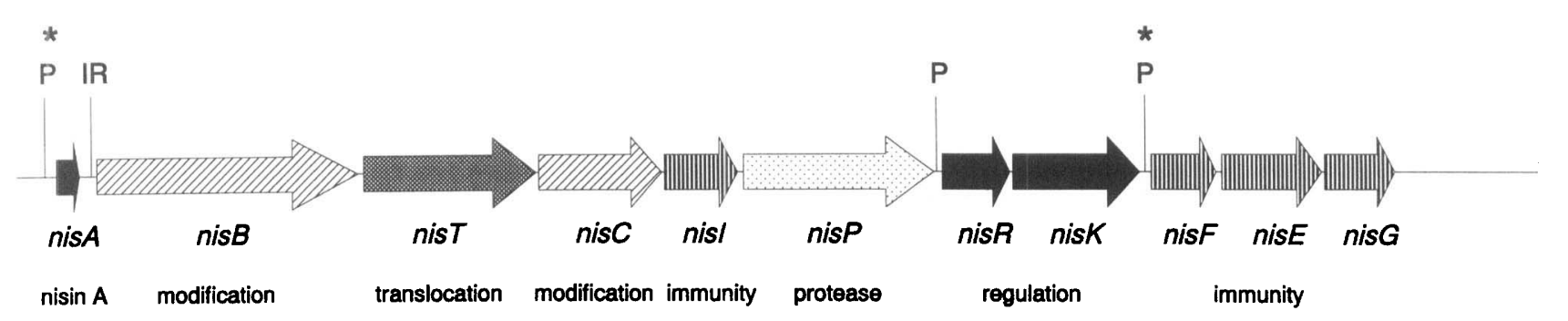

Fig. 1. Organization of nisin biosynthetic, regulatory and immunity genes. Regulated promoters are indicated by $P^{*}$ and constitutive promoters by P. An inverted repeat is indicated by IR.

\& Saris, 1996). nisI encodes a lipoprotein that is involved in immunity (Kuipers et al., 1993; Qiao et al., 1995) and nisFEG encode putative transporter proteins that probably, together with nisl, accomplish full nisin immunity of the producer strain (Siegers \& Entian, 1995; Dodd et al., 1996). nisP encodes an extracellular subtilisin-like protease involved in precursor processing (van der Meer et al., 1993;Qiao et al., 1996). nisR and nisK encode a response regulator (van der Meer et al., 1993) and a sensor of the histidine protein kinase family (de Vos et al., 1995a; Immonen et al., 1995; Siegers \& Entian, 1995), respectively, that belong to the class of twocomponent regulatory systems (Stock et al., 1990). It has been shown that both genes are involved in the regulation of nisin biosynthesis (van der Meer et al., 1993; Engelke et al., 1994). Recently, it has been demonstrated that fully modified nisin is the extracellular input signal for the sensor NisK (Kuipers et al., 1995). Small amounts of fully modified nisin can activate the transcription of its own structural gene, the transcription of the downstream genes, and transcription of nisFEG, via this two-component regulatory system (Kuipers et al., 1995; de Ruyter et al., 1996; Ra et al., 1996).

In this paper we describe disruptions in several genes of the nisin gene cluster, of which all except one were made in-frame to avoid polar effects on downstream genes. The effects of these disruptions on the transcription of nisin genes, nisin production and producer immunity were analysed. Remarkably, several levels of immunity could be distinguished in the knock-out strains relative to the wild-type strain, depending on the production levels of NisI and NisFEG, but the wild-type level could never be reached.

\section{METHODS}

Bacterial strains, plasmids and media. L. lactis strain NZ9700 (Kuipers et al., 1993) is a nisin A producing transconjugant, which was obtained from a mating between L. lactis MG1614 (Gasson, 1983) and the nisin A producer L. lactis NIZO R5 (Rauch \& de Vos, 1992). NZ9800 is a derivative of NZ9700, with a 4 bp deletion in the pronisin-encoding part of the nis $A$ gene, which is unable to produce nisin (Kuipers et al., 1993). L. lactis strains were grown in M17 broth (Difco) supplemented with $0.5 \%(\mathrm{w} / \mathrm{v})$ glucose or sucrose at $30^{\circ} \mathrm{C}$ without aeration Escherichia coli strain MC1061 (Casadaban et al., 1980) was used as a host strain for cloning experiments; it was grown in Tryptone Yeast (TY) medium (Sambrook et al., 1989) at $37^{\circ} \mathrm{C}$. Antibiotics were used in the following concentrations: ampicillin, $50 \mu \mathrm{g} \mathrm{ml}^{-1}$; erythromycin, $2.5 \mu \mathrm{g} \mathrm{ml}^{-1}$; chloramphenicol, $10 \mu \mathrm{g} \mathrm{ml}^{-1}$.

Construction of plasmids. The construction of the integrative plasmid pNZ9135, used for the disruption of the nisB gene by gene replacement, has been described previously (Kuipers et al., 1995). The gene replacement results in a $\Delta n i s B$ gene, in which the codons for amino acid residues 474-535 were specifically deleted. To construct the integrative plasmid pNZ9143 for disruption of the nisT gene, a $3.9 \mathrm{~kb}$ Sst $\mathrm{I}-\mathrm{Accl}$ fragment containing the nis $T$ gene and flanking regions was cloned into a SstI/AccI-digested pUC19 vector, which had an additional erythromycin resistance marker. The nis $T$ gene was changed by introducing a $231 \mathrm{bp}$ in-frame deletion in the middle of the gene; this was accomplished by removing an internal SpeI fragment, resulting in the removal of the codons for amino acid residues 318-395. To construct the singlecrossover integrative plasmid pNZ9134 (AnisC), an internal 753 bp NdeI-Ncol (filled in with Klenow) fragment of nis $C$ was cloned into a NdeI/Smal-digested pUC19 vector, which had an additional erythromycin resistance marker from pE194 (Leenhouts et al., 1991). To construct the integrative plasmid pNZ9147, a $4.7 \mathrm{kbp}$ SpeI-BclI fragment containing the nisI gene and flanking regions was cloned into a $\mathrm{XbaI} / \mathrm{BamHI}-$ digested pUC19 vector, which had an additional erythromycin resistance marker. The nisl gene was almost completely removed by introducing a $399 \mathrm{bp}$ in-frame deletion, resulting in removal of the codons for amino acid residues 57-190 of NisI. This was accomplished by removing an internal HpaI (partial digest)-AvaI (filled in with Klenow) fragment from the gene.

DNA, RNA and protein techniques. Plasmid and chromosomal DNA of L. lactis were isolated as described previously (Vos et al., 1989). L. lactis cells were transformed by electroporation (Holo \& Nes, 1989). Plasmid isolations from E. coli cells, and transformations of $E$. coli strains, were carried out according to established procedures (Sambrook et al., 1989). Restriction enzymes, T4 DNA ligase and other DNA-modifying enzymes were purchased from Gibco-BRL Life Technologies, New England Biolabs, Pharmacia or Promega and used as recommended by the manufacturers. Cloning procedures, radiolabelling of DNA fragments, agarose-gel electrophoresis and Southern blot hybridizations were carried out according to established procedures (Sambrook et al., 1989). PCRs were performed using the conditions described before (Kuipers et 
Table 1. Primers used in this study

\begin{tabular}{|lll|}
\hline Primer & \multicolumn{1}{c|}{ Sequence } & \multicolumn{1}{c|}{ Location } \\
\hline 1 & 5'-GAGTCCGAACCGAGTAC-3' & nisB \\
2 & 5'-GAGTTGAAATGTCTCGTG-3' & nisB \\
3 & 5'-GGAACATGGAACATTGGG-3' & nisT \\
4 & 5'-CATATGTTGAAAGTTTGCTAAC-3' $^{\prime}$ & nisC \\
5 & 5'-GAGAAGATATTTAATACTTATTGTGG-3' & nisI \\
6 & 5'-ATGCTTCAGTAAGAGATTTTCCTC-3' & nisI \\
7 & 5'-GTTTTGATGCGTCGCAACTTCATAG-3' & nisR \\
NIS121 & 5'-CTGAITAIATTCTGAAITTGTT-3' & Promoter fragment of \\
& & nisA and nisF \\
\hline
\end{tabular}

al., 1991). DNA sequencing was performed by the dideoxynucleotide chain-termination method (Sanger et al., 1977). Oligonucleotides, used as primers in sequencing reactions and for PCR, were purchased from Pharmacia. Primers used in this study are listed in Table 1. RNA isolation, Northern blotting and subsequent hybridization with radiolabelled probes were performed as described previously (Ra et al., 1995, 1996). The methods for nisin immunity assays for L. lactis (Kuipers et al., 1993) and nisin induction experiments (Kuipers et al., 1995) have also been described before. Pre-induction was performed by adding nisin $\mathrm{A}\left(0 \cdot 01 \mu \mathrm{g} \mathrm{m}^{-1}\right)$ to the freshly diluted culture. The nisin produced was quantified using an agar diffusion test with Micrococcus luteus as indicator. Dilution series of the samples were assayed in order to determine the minimal inhibitory concentration (MIC). This MIC value was used to compare percentage differences, which gives a more reliable estimation than values based on arithmetic measures of diffusion of nisin through agar. Western analyses were done with the KH1422 NisI-specific antiserum as described previously (Qiao et al., 1995).

Introduction of in-frame deletions in chromosomal nisin genes by gene replacement. The plasmids pNZ9135 ( $\triangle$ nisB), pNZ9143 ( $\Delta$ nis $T)$ and pNZ9147 ( $\Delta n i s I)$, all pUC19 derivatives that cannot replicate in $L$. lactis, were used to transform the nisin A producing L. lactis NZ9700. Erythromycin-resistant $\left(\mathrm{Em}^{r}\right)$ colonies were obtained that were the result of the integration of the plasmid caused by a recombination event involving one of the flanking regions on the plasmid and the corresponding regions on the chromosome. After subculturing for 100-200 generations in the absence of erythromycin, Em colonies were obtained as a result of a second recombination event with the flanking region on the other side of the disrupted region relative to the first recombination event. The expected disruptions in the chromosomal genes were confirmed by PCR analysis, Southern analysis and sequence analysis.

\section{RESULTS}

\section{In-frame deletions in nisB, nisT and nisl and single- crossover disruption of nisC}

After electroporation of NZ9700 with pNZ9135 to disrupt the nisB gene, one of several $\mathrm{Em}^{\mathrm{r}}$ colonies with the plasmid integrated in the correct location of the chromosome as judged by Southern analysis was grown without erythromycin. After plating, several $\mathrm{Em}^{\mathrm{s}}$ colonies were obtained in which a second recombination event had occurred resulting in excision of the plasmid from the chromosome. Southern blot hybridization, PCR analysis with primers 1 and 2 (Table 1) and sequence analysis confirmed the expected in-frame disruption of the nis $B$ gene on the chromosome in one of the colonies. The resulting strain was named NZ9735. Using a similar approach with other integrative plasmids, in-frame deletions were also obtained in nis $T$ (NZ9743) and nisI (NZ9747). Attempts to obtain a double-crossover integration to disrupt the nis $C$ gene on the chromosome of L. lactis NZ9700 were unsuccessful. After changing the strategy to obtain single-crossover integrants, Southern blot analysis of a picked $\mathrm{Em}^{\mathrm{r}}$ colony revealed that four copies of pNZ9134 had integrated in the same spot of the nis $C$ gene on the chromosome. The integrated plasmids could not be excised by culturing without erythromycin.

\section{Effects of in-frame deletions and plasmid integration on nisin production and immunity}

The effects of the various gene disruptions in the nisin gene cluster on nisin production were studied. Supernatants of overnight cultures were tested in a bioassay, and TCA-precipitated supernatants were analysed by SDS-PAGE for the production of nisin or nisin precursor (Table 2). Nisin production was blocked in all cases with one exception, i.e. strain NZ9747, carrying the inframe deletion in the nisI gene, which was still able to produce nisin, although the production level was reduced to approximately $20-40 \%$ of that of the wildtype NZ9700. This confirms that intact nisB, nisC and nis $T$ genes are essential for the production of active nisin in the supernatant and shows for the first time that intact nisI is not essential.

A disruption in the nisI gene resulted in an immunity level that was still approximately $10-30 \%$ of the maximum immunity level of the wild-type nisin-producing strain. Disruptions in nisB, nis $T$ and nis $C$ resulted in very low immunity levels, comparable to the immunity level of the $\triangle$ nis A strain NZ9800 (Kuipers et al., 1993), which is more than 100 times lower than that of the wild-type nisin producer NZ9700, but still much higher than that of strain MG1614, carrying no nisin 
Table 2. Effects of gene disruptions on nisin production, immunity and transcription of nisFEG

The amount of nisin used for pre-induction of the cultures was $0.01 \mu \mathrm{g} \mathrm{ml}^{-1}$. Nisin production levels:,$+++ 100 \% ;++, 20-40 \%$; - , no production. Immunity levels:,$++++ 100 \% ;+++30-60 \% ;++, 10-30 \%,+, 5-10 \%,-,<1 \%$. nisFEG transcript levels:,$++++ 100 \% ;+++, 50-70 \% ;++, 10-30 \%,-,<1 \%$.

\begin{tabular}{|c|c|c|c|c|c|}
\hline \multirow[t]{2}{*}{ Strain } & \multirow{2}{*}{$\begin{array}{c}\text { Extracellular } \\
\text { nisin production }\end{array}$} & \multicolumn{2}{|c|}{ Immunity } & \multicolumn{2}{|c|}{ Transcription of nisFEG } \\
\hline & & $\begin{array}{c}\text { No } \\
\text { induction }\end{array}$ & $\begin{array}{l}\text { Pre-induction } \\
\text { with nisin }\end{array}$ & $\begin{array}{c}\text { No } \\
\text { induction }\end{array}$ & $\begin{array}{l}\text { Pre-induction } \\
\text { with nisin }\end{array}$ \\
\hline MG1614 & - & - & - & - & - \\
\hline NZ9700 & +++ & ++++ & $++t$ & ++++ & ++++ \\
\hline NZ9800 $\Delta$ nisA & - & - & ++ & - & ++ \\
\hline NZ9735 $\Delta$ nisB & - & - & ++ & - & ++ \\
\hline NZ9743 $\Delta$ nis T & - & - & ++ & - & ++ \\
\hline $\mathrm{NZ9734} \Delta$ nisC & - & - & + & - & ++ \\
\hline NZ9747 $\Delta$ nisI & ++ & ++ & ++ & +++ & +++ \\
\hline
\end{tabular}

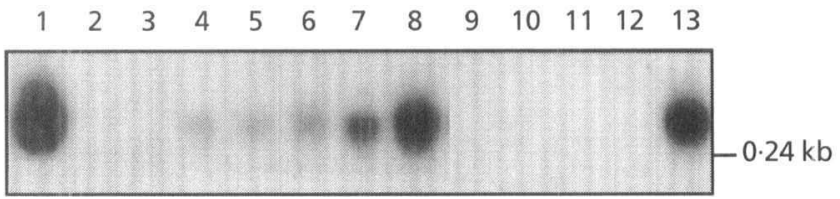

Fig. 2. Northern blot using total RNA from various $L$. lactis strains with the structural nisA gene as a probe. Lanes: 1, NZ9700; 2 and 3, MG1614; 4 and 9, NZ9800 ( $\Delta$ nisA); 5 and 10, NZ9735 ( $\Delta$ nisB); 6 and 11, 9743 ( $\Delta$ nis $T) ; 7$ and 12, NZ9734 $(\Delta$ nisC); 8 and 13, NZ9747 ( $\Delta$ nisl). The RNA in lanes 4-7 was isolated from cells that had been pre-induced with $0.01 \mu \mathrm{g}$ nisin A $\mathrm{ml}^{-1}$.

genes. However, when cells were pre-induced with $0.01 \mu \mathrm{g}$ nisin $\mathrm{A} \mathrm{ml}^{-1}$, the immunity levels were elevated to approximately $20 \%$ of the wild-type level (Table 2 ). Although no production of nisin was found in the extracellular medium after induction, it is possible that an intracellular, partly modified precursor nisin is

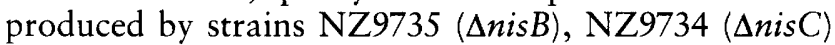
and NZ9743 $(\Delta n i s T)$. However, we were not able to detect any accumulation of intracellular nisin precursor with antibodies against the nisin leader peptide. The presence of a partly modified nisin precursor secreted by nisin-induced cells of strains NZ9735 or NZ9734 could also not be detected.

\section{Effects of gene disruptions and nisin induction on transcription of nisin immunity genes}

Strains NZ9735, NZ9743, NZ9734 and NZ9747, with disruptions in the nisB, nisT, nis $C$ and nisI genes, respectively, were checked for the presence of a nis $A$ and a nisFEG transcript by Northern hybridizations. In all cases, except in NZ9747, nis $A$ and nisFEG transcription was absent (Fig. 2, Table 2). Addition of nisin to the

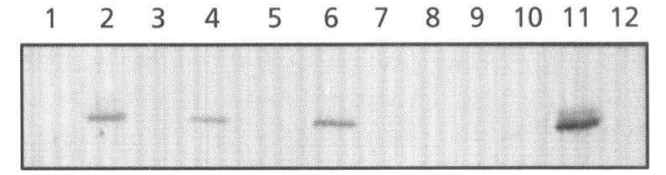

Fig. 3. Western blotting analysis of cells of L. lactis strains. A polyclonal Nisl-specific antiserum was used to recognize the Nisl protein. Lanes: 1 and 2, NZ9800 ( $\triangle$ nisA); 3 and 4, NZ9735 $(\Delta$ nisB); 5 and 6, NZ9743 ( $\Delta$ nisT); 7 and $8, N Z 9734$ ( $\Delta$ nisC); 9 and 10, NZ9747 ( $\Delta$ nisI); 11, NZ9700; 12, MG1614. The cells of the samples in lanes $2,4,6$ and 8 were pre-induced with $0.01 \mu \mathrm{g}$ nisin $\mathrm{A} \mathrm{ml}^{-1}$.

growing cultures restored the transcription of nis $A$ and nisFEG in all knock-out strains (Fig. 2, Table 2). In accordance with this, Western blotting analysis with NisI-specific antiserum showed that without induction, NisI is not produced in the mutant strains, whereas induced cells produce NisI, except strain NZ9747 ( $\Delta$ nisI) and strain NZ9734 (AnisC) (Fig. 3). In strain NZ9734 four plasmids had integrated into the nis $C$ gene and this is likely to hinder transcriptional readthrough of the nis $C$ to the nisI gene from the induced nis $A$ promoter. Interestingly, this strain was also less immune than the other knock-out strains, even after induction.

\section{Analysis of the number of promoters similar to the nis $A$ and nisF promoters}

In order to evaluate whether nisin induction could potentially initiate the transcription of genes other than nisABTCIPRKFEG, a Southern analysis was performed with EcoRI/EcoRV-digested chromosomal DNA of a nisin-producing strain using a degenerate oligonucleotide probe which hybridizes to the conserved regions of the two known nisin promoters. The expected size of the fragments with these promoters is 3 and 


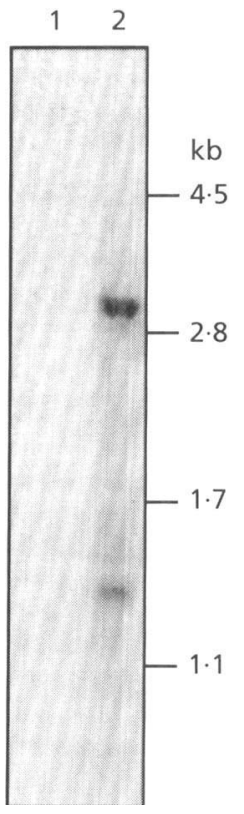

Fig. 4. Southern blot analysis of L. lactis strain MG1614, which does not contain the nisin operons (lane 1), and the nisinproducing strain NZ9700 (lane 2). A degenerate probe (NIS121) recognizing the homologous sequences of the nis $A$ and nis $F$ promoters was used.

$1 \cdot 3 \mathrm{~kb}$. The Southern blot result (Fig. 4) did not visualize any other bands than the expected ones, indicating that a nisin producer has no additional promoters in the chromosome with high homology to the nis $A$ or nisF promoters.

\section{DISCUSSION}

Gene disruptions with polar effects have previously been reported for the nis $A$, nis $B$, nis $T$, nis $C$, nisl, nisP, nisR, nisF and nisE genes (Kuipers et al., 1993; Siegers \& Entian, 1995; Siegers et al., 1996; Dodd et al., 1996; Ra et al., 1996; Qiao et al., 1996). However, correlating a phenotype to a specific locus using a mutant strain that contains a polar mutation, especially if the mutation is in a large operon like the biosynthetic operon expressed from the nis $A$ promoter, is not without risk. To avoid possible ambiguities, in-frame deletions were constructed in the nis $B$, nis $T$ and nisI genes. Attempts to obtain an in-frame deletion in the nis $C$ gene were unsuccessful and resulted in a strain with this gene disrupted by plasmid integration. Nisin production had ceased in the strains with the in-frame mutations in nis $B$ and nis $T$ and could not be restored by addition of subinhibitory amounts of nisin. Transcription of the genes downstream of the mutated nisB or nis $T$ genes was deduced to take place, because after nisin induction the product of the downstream nisl gene was detected in Western analysis using a NisI-specific antiserum. The fact that all nisin genes were transcribed after nisin induction and still no nisin was produced by the NZ9735 and NZ9743 strains conclusively demonstrates that NisB and Nis T are essential for the biosynthesis of nisin. The putative structure of NisT and the recent results of Siegers et al. (1996) and Qiao \& Saris (1996) suggest that NisT is involved in transport of precursor nisin and NisB in dehydration of the nisin precursor.

Analysis of the NZ9734 strain with the disrupted nisC gene showed that the plasmid insertion in nis $C$ resulted in polar effects as judged from the fact that that no NisI protein could be detected after nisin induction. Because no modified nisin precursor was secreted by strain NZ9734 upon nisin induction, as would be expected if $\mathrm{NisC}$ was not essential for the biosynthesis of nisin, it can be concluded that NisC is essential for nisin maturation.

Nisin induction of the knock-out strains $(\Delta n i s B, \Delta n i s T$, $\Delta n i s C$ and $\Delta n i s I)$ did not result in full restoration of transcription of the nisin operons. A lower transcription level of the nisin operons is likely to explain the lower immunity level of induced mutant strains compared to nisin-producing strains (Dodd et al., 1996). A wild-type level of transcription of the nisin operons might require gradually increasing nisin concentrations as in a nisin producer and such fine-tuning may not occur when nisin is externally added at a certain time point to mutant strains. The increase in immunity levels of the nisin mutant strains by nisin induction could also be a result of induction of nisin-inducible genes other than nisABTCIPRKFEG. If such genes did exist, their promoter would most likely share sequence similarity with the nisin-inducible promoters in front of nis $A$ and nis $F$ (de Ruyter et al., 1996; Ra et al., 1996). The Southern blot analysis of DNA of a nisin-producing strain using a degenerate probe recognizing the conserved sequences of the nis $A$ and nisF promoters (de Ruyter et al., 1996; $\mathrm{Ra}$ et al., 1996) suggests that a nisin-producing strain does not contain additional nisin-inducible promoters. Therefore, the increase in the level of nisin immunity of the nisin mutant strains observed after nisin induction is likely to be the sole result of the increased transcription of the two known nisin-inducible operons, i.e. nisABTCIP and nisFEG.

The NZ9747 strain with a deletion in the nisI gene did not produce the NisI protein but could still produce nisin. The lack of the NisI immunity protein affected the growth of the strain. It did not grow to as high cell densities as the parental strain and the maximum amount of nisin produced was also lower: approximately $20 \%$ of the highest amount that could be produced by the wild-type strain. The cells of strain NZ9747 could tolerate the amount of nisin that they produced themselves, probably due to the expression of the nisFEG genes, but the sensitivity to externally added nisin was approximately five times higher than in the wild-type. The nisin immunity level of strain NZ9747 showed that without the NisI lipoprotein the NisF, NisE and NisG immunity proteins can protect the cells to approximately $20 \%$ of the wild-type level. Duan et al. (1996) described from L. lactis a plasmid-encoded nisin 
resistance determinant consisting of only the nisRKFEG genes. The presence of this nisin resistance plasmid resulted in an immunity level of approximately $20 \%$ of a wild-type nisin producer. The nisin immunity level of strain NZ9747 corresponds well to the nisin resistance level of the nisin resistance plasmid containing the nisRKFEG genes. From these results some conclusions can be drawn concerning the question whether NisI cooperates with the NisFEG polypeptides or whether they represent separate immunity systems. Expressed to wild-type and higher levels without other nis-encoded genes NisI gives only $1-4 \%$ of the wild-type immunity level (Kuipers et al., 1993; Qiao et al., 1995). If NisI represents a non-cooperating immunity system, then the question arises why the immunity level of NZ9747 is only $20 \%$ of the wild-type level and is not in the range of $>95 \%$ as would be expected if NisI formed an independent immunity system. Therefore, NisI clearly cooperates with some of the transposon-encoded polypeptides, probably with the NisFEG polypeptides. The observed $80 \%$ reduction of nisin immunity in the NisIdeficient strain can be partly explained by assuming that the efficiency of the immunity proteins is also influenced by the presence of functional complexes with other nisencoded membrane proteins, e.g. NisB, NisP or NisT. This has been suggested by previous results of Kuipers $e t$ al. (1993) showing that expression of nisI resulted in at most $1-4 \%$ of wild-type immunity, whereas when nis was expressed together with the nisABTC genes the immunity level was higher, ranging between 8 and $20 \%$ of the wild-type level. Thus, full nisin immunity seems to require nisin production and fully induced nisI and nisFEG genes. This notion is further supported by recent studies showing that the production of antisense-nisEG or antisense-nis $G$ RNA severely reduced the immunity levels in the L. lactis strain tested (Immonen \& Saris, 1998).

The killing activity of nisin requires pore formation in the target cell. It has been speculated that NisI as a lipoprotein could destabilize this pore formation (Entian \& de Vos 1996; Saris et al., 1996) or assist the putative transport function of NisFEG. Recently Qiao (1996) has shown by circular dichroism (CD) spectroscopy and biomolecular interaction analysis (BIA) that purified Nisl does indeed have physical interactions with nisin. On the basis of sequence homology the nisFEG-encoded proteins belong to the family of $\mathrm{ABC}$ transporters (Siegers \& Entian, 1995), which strongly suggests that nisin immunity is dependent on nisin translocation. Our present view of nisin immunity comprises cooperative interactions of NisI with the putative NisFEG complex, in which translocation of nisin from the membrane to the cell exterior by NisFEG activity is mediated or facilitated by NisI interactions with nisin.

\section{ACKNOWLEDGEMENTS}

We thank Roland Siezen, Michiel Kleerebezem and Cindy van Kraaij for critically reading the manuscript. This work was in part supported by contract BIOT-CT91-0265 of the BRIDGE programme of the European Union.

\section{REFERENCES}

Buchman, G. W., Banerjee, S. \& Hansen, J. N. (1988). Structure, expression and evolution of a gene encoding the precursor nisin, a small peptide antibiotic. J Biol Chem 263, 16260-16266.

Casadaban, M. J., Chou, J. \& Cohen, S. N. (1980). In vitro gene fusions that join an enzymatically active $\beta$-galactosidase segment to amino-terminal fragments of exogenous proteins: Escherichia coli plasmid vectors for the detection and cloning of transcriptional initiation signals. J Bacteriol 143, 971-980.

Delves-Broughton, J., Blackburn, P., Evans, R. J. \& Hugenholtz, J. (1996). Applications of the bacteriocin nisin. Antonie Leeuwenhoek 69, 193-202.

Dodd, H. M., Horn, N., Chan, W. C., Giffard, C. J., Bycroft, B. W., Roberts, G. C. K. \& Gasson, M. J. (1996). Molecular analysis of the regulation of nisin immunity. Microbiology 142, 2385-2392.

Duan, K., Harvey, M. L., Liu, C.-Q. \& Dunn, N. W. (1996). Identification and characterization of a mobilizing plasmid, pND300, in Lactococcus lactis M189 and its encoded nisin resistance determinant. J Appl Bacteriol 81, 493-500.

Engelke, G., Gutowski-Eckel, Z., Hammelmann, M. \& Entian, K.-D. (1992). Biosynthesis of the lantibiotic nisin: genomic organization and localization of the NisB protein. Appl Environ Microbiol 58, 3730-3743.

Engelke, G., Gutowski-Eckel, Z., Kiesau, P., Siegers, K., Hammelmann, M. \& Entian, K.-D. (1994). Regulation of nisin biosynthesis and immunity in Lactococcus lactis 6F3. Appl Environ Microbiol 60, 814-825.

Entian, K.-D. \& de Vos, W. M. (1996). Genetics of subtilin and nisin biosynthesis. Antonie Leeuwenhoek 69, 109-177.

Gasson, M. J. (1983). Plasmid complements of Strepococcus lactis NCDO 712 and other lactic streptococci after protoplast-induced curing. J Bacteriol 154, 1-9.

Gross, E. \& Morell, J. L. (1971). The structure of nisin. J Am Chem Soc 93, 4634-4635.

Holo, H. \& Nes, I. F. (1989). High-frequency transformation, by electroporation, of Lactococcus lactis subsp. cremoris grown with glycine in osmotically stabilized media. Appl Environ Microbiol 55, 3119-3123.

Hurst, A. (1981). Nisin. Adv Appl Microbiol 27, 85-123.

Immonen, T. \& Saris, P. E. J. (1998). Characterization of the nisFEG operon of the nisin $\mathrm{Z}$ producing Lactococcus lactis subsp. lactis N8 strain. DNA Seq 67, 1-12.

Immonen, T., Ye, S., Ra, R., Qiao, M., Paulin, L. \& Saris, P. E. J. (1995). The codon usage of the nis $Z$ operon in Lactococcus lactis N8 suggests a non-lactococcal origin of the conjugative nisinsucrose transposon. DNA Seq 5, 203-208.

Kaletta, C. \& Entian, K.-D. (1989). Nisin, a peptide antibiotic: cloning and sequencing of the nis $A$ gene and posttranslational processing of its peptide product. J Bacteriol 171, 1597-1601.

Kuipers, O. P., Boot, H. J. \& de Vos, W. M. (1991). Efficient random mutagenesis method with adjustable mutation frequency by use of PCR and dITP. Nucleic Acids Res 19, 4558.

Kuipers, O. P., Beerthuyzen, M. M., Siezen, R. J. \& de Vos, W. M. (1993). Characterization of the nisin gene cluster nisABTCIPR of Lactococcus lactis; requirement of expression of nis $A$ and nisI genes for development of immunity. Eur J Biochem 216, 281-291.

Kuipers, O. P., Beerthuyzen, M. M., de Ruyter, P. G. G. A., Luesink, E. J. \& de Vos, W. M. (1995). Autoregulation of nisin biosynthesis in Lactococcus lactis by signal transduction. J Biol Chem 270, 27299-27304.

Leenhouts, K. J., Gietema, J., Kok, J. \& Venema, G. (1991). 
Chromosomal stabilization of the proteinase genes in Lactococcus lactis. Appl Environ Microbiol 57, 2568-2575.

van der Meer, J. R., Polman, J., Beerthuyzen, M. M., Siezen, R. J., Kuipers, O. P. \& de Vos, W. M. (1993). Characterization of the Lactococcus lactis nisin A operon genes nisP, encoding a subtilisin-like serine protease involved in precursor processing, and nisR, encoding a regulatory protein involved in nisin biosynthesis. J Bacteriol 175, 2578-2588.

Qiao, M. (1996). Lantibiotic nisin of Lactococcus lactis: biosynthesis, immunity and regulation. Doctoral thesis, University of Helsinki. ISBN 952-90-8180.

Qiao, M. \& Saris, P. E. J. (1996). Evidence for a role of NisT in transport of the lantibiotic nisin produced by Lactococcus lactis N8. FEMS Microbiol Lett 144, 89-93.

Qiao, M., Immonen, T., Koponen, O. \& Saris, P. E. J. (1995). The cellular location and effect on nisin immunity of the Nisl protein from Lactococcus lactis N8 expressed in Escherichia coli and $L$. lactis. FEMS Microbiol Lett 131, 75-80.

Qiao, M., Ye, S., Koponen, O., Ra, R., Usabiaga, M., Immonen, T. \& Saris, P. E. J. (1996). Regulation of the nisin operons in Lactococcus lactis. J Appl Bacteriol 80, 626-634.

Ra, R. \& Saris, P. E. J. (1995). Characterization of procaryotic mRNAs by RT/PCR technique. BioTechniques 18, 792-795.

Ra, R., Qiao, M., Immonen, T., Pujana, I. \& Saris, P. E. J. (1996). Genes responsible for nisin synthesis, regulation and immunity form a regulon of two operons and are induced by nisin in Lactococcus lactis N8. Microbiology 142, 1281-1288.

Rauch, P. J. G. \& de Vos, W. M. (1992). Characterization of the novel nisin-sucrose conjugative transposon $\operatorname{Tn} 5276$ and its integration in Lactococcus lactis. J Bacteriol 174, 1280-1287.

de Ruyter, P. G. G. A., Kuipers, O. P., Beerthuyzen, M. M., van Alen, I. J. \& de Vos, W. M. (1996). Functional analysis of promoters in the nisin gene cluster of Lactococcus lactis. J Bacteriol 178, 3434-3439.

Sambrook, J., Fritsch, E. F. \& Maniatis, T. (1989). Molecular Cloning: a Laboratory Manual, 2nd edn. Cold Spring Harbor, NY : Cold Spring Harbor Laboratory.
Sanger, F., Nicklen, S. \& Coulson, A. R. (1977). DNA sequencing with chain-terminating inhibitors. Proc Natl Acad Sci USA 74, 5463-5467.

Saris, P. E. J., Immonen, T., Reis, M. \& Sahl, H.-G. (1996). Immunity to lantibiotics. Antonie Leeuwenhoek 69, 151-159.

Siegers, K. \& Entian, K.-D. (1995). Genes involved in immunity to the lantibiotic nisin produced by Lactococcus lactis 6F3. Appl Environ Microbiol 61, 1082-1089.

Siegers, K., Heinzman, S. \& Entian, K.-D. (1996). Biosynthesis of lantibiotic nisin - posttranslational modification of its prepeptide occurs at a multimeric membrane-associated lanthionine synthetase complex. J Biol Chem 271, 12294-12301.

Steen, M. T., Chung, Y. J. \& Hansen, J. N. (1991). Characterization of the nisin gene as part of a polycistronic operon in the chromosome of Lactococcus lactis ATCC 11454. Appl Environ Microbiol 57, 1181-1188.

Stock, J. B., Stock, A. M. \& Mottonen, J. M. (1990). Signal transduction in bacteria. Nature 344, 395-400.

Vos, P., van Asseldonk, M., van Jeveren, F., Siezen, R. J., Simons, G. \& de Vos, W. M. (1989). A maturation protein is essential for the production of active forms of Lactococcus lactis SK11 serine proteinase located in or secreted from the cell envelope. J Bacteriol 171, 2795-2802.

de Vos, W. M., Beerthuyzen, M. M., Luesink, E. L. \& Kuipers, O. P. (1995a). Genetics of the nisin operon and the sucrose-nisin conjugative transposon Tn5276. In Genetics of Streptococci, Enterococci and Lactococci (Development of Biological Standards vol. 85), pp. 617-625. Edited by J. J. Ferretti, M. S. Gilmore, T. R. Klaenhammer \& F. Brown. Basel: Karger.

de Vos, W. M., Kuipers, O. P., van der Meer, J. R. \& Siezen, R. J. (1995b). Maturation pathway of nisin and other lantibiotics: post-translationally modified antimicrobial peptides exported by Gram-positive bacteria. Mol Microbiol 17, 429-437.

Received 25 November 1998; revised 8 February 1999; accepted 12 February 1999. 